\title{
The Possible Protective Role of Vitamin C Against Monosodium Glutamate Induced Structural Changes of Adrenal Cortex of the Adult Male Albino Rat: Histological and Immunohistochemical Study
}

\author{
Enas Anwar Bekheet and Marian Mokhtar Shokry
}

Anatomy Department, Faculty of Medicine, Ain Shams University, Egypt

\begin{abstract}
Introduction: Monosodium glutamate (MSG) is a popularly used taste enhancer. MSG proved to cause many degenerative diseases and oxidative damages. Vitamin $\mathrm{C}$ has an antioxidant property.

Aim: This work aimed to study the possible protective role of vitamin $\mathrm{C}$ against Monosodium glutamate induced structural changes of the adrenal cortex.

Material and Methods: Forty-five adult male albino rats were used in this study, aged from 4-6 months and weighting 180$200 \mathrm{Kg}$. Animals were divided into three equal groups. Group I: It was composed of fifteen rats and was further subdivided into three equal subgroups; Subgroup IA: included 5 rats that kept as negative control. Subgroup IB: included 5 rats that received $1 \mathrm{ml}$ of distilled water for 8 weeks and Subgroup IC included 5 rats that received vitamin $\mathrm{C}$ in a dose of $0.3 \mathrm{mg} / \mathrm{Kg}$ body weight /day for 8 weeks. Group II: It included fifteen adult male rats that received $4 \mathrm{mg} / \mathrm{Kg}$ body weight/ day of MSG for 8 weeks. Group III: It included fifteen rats that received MSG as in group II and vitamin C in a dose of $0.3 \mathrm{mg} / \mathrm{Kg}$ body weight /day for 8 weeks.

Results: The present study revealed that MSG induced histological changes of adrenal cortex in the form of disorganized structure of zona glomerulosa and zona fasciculata with increased accumulation of the cytoplasmic droplets and thinning of the capsule. Group III that received vitamin $\mathrm{C}$ revealed evident improvement of these changes.

Conclusion: Monosodium glutamate led to histoarchitectural changes of adrenal cortex. However, vitamin $\mathrm{C}$ greatly improved such changes.
\end{abstract}

Received: 24 July 2019, Accepted: 31 August 2019

Key Words: Cisplatin, ehrlich ascitescarcinoma, skeletal muscle, yeast (s. cerevisiae).

Corresponding Author: Enas Anwar Bekheet, MD, Anatomy Department, Faculty of Medicine, Ain Shams University, Egypt, Tel.: +20 1224037554, E-mail: eno.anatomy@yahoo.com

ISSN: 1110-0559, Vol. 43, No. 1

\section{INTRODUCTION}

A variety of food additives are widely used in food preservation, coloring and sweetening ${ }^{[1]}$. One of these additives is monosodium glutamate (MSG) which is popularly used as a taste enhancer of canned food, potato chips, frozen food, and fast food. MSG is the sodium salt of the non-essential amino acid glutamic acid ${ }^{[2]}$. MSG provides its flavoring effect through releasing the free glutamate which then binds to taste receptors and stimulates the taste nerves leading to the unique umami taste of MSG, that taste differs from the four classic known tastes of sour, sweet, salty, and bitter ${ }^{[3]}$. MSG was approved by the Food and Drug Administration in $1995^{[4]}$. However, unintentional abuse of MSG may occur because of its abundance use in food preparations especially those without labelling ${ }^{[5]}$. Higher doses of MSG proved to cause many degenerative effects such as, neurological degenerative disorders Alzheimer's disease and Parkinson's disease ${ }^{[6,7]}$, testicular degeneration, sperm abnormalities ${ }^{[8,9]}$ and ovarian atrophic changes ${ }^{[10,11]}$.
Vitamin C (Ascorbic Acid) presents naturally in fresh fruits and vegetables, the synthetic forms of vitamin $\mathrm{C}$ were reported to have similar chemical structure and biological effects to natural ones ${ }^{[12]}$. Vitamin $\mathrm{C}$ has an antioxidant property ${ }^{[13]}$.

Adrenal glands are endocrine glands which are essential in controlling body homeostasis ${ }^{[14]}$. Previous studies linked adrenal damage that occurred with chronic consumption of MSG to oxidative stress and excitotoxic effect of glutamate on neurons ${ }^{[15,16]}$. In addition, vitamin $\mathrm{C}$ together with MSG may be present in diet. Therefore, the present work designed to study the possible protective role of vitamin $\mathrm{C}$ against MSG induced structural changes of adrenal cortex.

\section{MATERIAL AND METHODS}

\section{Chemicals}

MSG was purchased in the form of powder $(500 \mathrm{gm} / \mathrm{pack})$ from El-Gomhouria Company for trading medicine, Egypt. 
Vitamin C was purchased from Sigma-Aldrich Chemicals Company in the form of powder $(100 \mathrm{gm} /$ bottle) (St. Louis, USA).

\section{Animals}

Forty-five adult male albino rats were used in this study, aged from 4-6 months and weighting 180 -200 gm, they were obtained and locally bred at the animal house at medical research center of Faculty of Medicine, AinShams University. Rats were housed in metal cages in a room temperature with regular dark/light cycles and good ventilation. Diet and water access were freely allowed. The experiment followed the guidelines of Ain Shams University Ethics Committee. All rats were kept under the same circumstances throughout the experiment.

\section{Experimental Protocol}

Animals were equally divided into three groups as follows:

Group I (Control Group): It was composed of fifteen rats and was further equally subdivided into three subgroups:

Subgroup IA (Negative Control): included 5 rats that received nothing but food and water for 8 weeks.

Subgroup IB (Vehicle Control): included 5 rats that received $1 \mathrm{ml}$ of distilled water and given orally by a gastric tube for 8 weeks.

Subgroup IC (Vitamin C Control): included 5 rats that received vitamin $\mathrm{C}$ in a dose of $0.3 \mathrm{mg} / \mathrm{Kg}$ body weight / day dissolved in $1 \mathrm{ml}$ of distilled water and given orally by a gastric tube for 8 weeks.

Group II (MSG Group): It included fifteen rats that received $4 \mathrm{mg} / \mathrm{Kg}$ body weight/ day of $\mathrm{MSG}^{[5]}$, the calculated dose was dissolved in $1 \mathrm{ml}$ of distilled water and given orally by a gastric tube for 8 weeks.

Group III (MSG + Vitamin C): It included fifteen rats that received MSG as in group II and vitamin C in a dose of $0.3 \mathrm{mg} / \mathrm{gm}$ body weight /day ${ }^{[17]}$ dissolved in $1 \mathrm{ml}$ of distilled water and given orally by a gastric tube for 8 weeks. By the end of the experimental periods, animals were anesthetized with diethyl ether, the adrenal glands were carefully dissected and processed for light microscopic examination. The rats were then killed by decapitation after collection of the specimens.

\section{Processing of samples}

\section{Preparation of paraffin blocks and staining methods}

Adrenal gland specimens were fixed in $10 \%$ buffered formalin, processed and embedded in paraffin blocks, sectioned at $5 \mu \mathrm{m}$, cut and stained by Hematoxylin and
$\operatorname{Eosin}^{[18]}$ to study the general histological features of the gland and other sections were stained with Masson's trichrome stain to clarify the collagen fibers ${ }^{[19]}$.

Immunohistochemical study for caspase 3 was used as an indicator of apoptosis, sections washed in phosphatebuffered saline for $5 \mathrm{~min}$ and then incubated with antibody to cleaved caspase 3 at a dilution of 1:200 (Invitrogen, Sweden AB Stockholm Sweden) overnight at $4^{\circ} \mathrm{C}$. Then washed and incubated with (1:500) secondary goat-antirabbit antibody (Invitrogen, Molecular Probes, Eugene, Oregon, USA) for $1 \mathrm{~h}$ in room temperature. Slides were then incubated in 3,3-diaminobenzidene for $15 \mathrm{~min}$ and counterstained by Mayer's hematoxylin, dehydrated and mounted by dibutyl phthalate in xylene (DPX) ${ }^{[20]}$.

\section{Preparation of epon blocks for semithin sections and staining method}

Adrenal gland specimens were fixed immediately in $2.5 \%$ glutaraldehyde in phosphate buffer for 3 hours. Fixed tissue samples were washed with phosphate buffer and post fixed in $1 \%$ osmium tetra oxide. After dehydration in ascending grades of alcohol and embedding in epon, semithin sections one um thick were cut using L.K.B. ultra-microtome, picked up on a gelatinized glass slides and stained with toluidine blue ${ }^{[21]}$.

Stained sections were examined and photographed using light microscope (Olympus 268M microscope) equipped with an automatic photomicrographic camera system.

\section{Image analysis}

Morphometric analysis was carried out on routine Hx. and E. stained slides using image analyzer Leica $\mathrm{Q}$ win V.3 program on a computer in the histology department, Faculty of Medicine, Ain Shams University. The computer was connected to a Leica DM2500 microscope (Wetzlar, Germany). Six randomly chosen fields in six sections obtained from six different animals from the same group were used for measuring the thickness of the adrenal capsule and the number of caspase positive cells of zona fasciculata $(\mathrm{ZF}) /$ field in all groups. pixels were calibrated for actual measurements in micrometer. The magnification used was 400X for the thickness of the adrenal capsule and $1000 \mathrm{X}$ for the number of caspase positive cells of ZF.

\section{Statistical analysis}

Data analysis was performed using MedCalc ${ }^{\circledR}$ Version 11.1.1.0 for Windows (MedCalc Software, Belgium) and Microsoft Office Excel 2010 (Microsoft, USA) where analyses of variance (ANOVA test), mean, standard deviation (SD) and T-test were done. T-test result was considered highly significant when $P \leq 0.001$, significant when $P \leq 0.05$ and insignificant when $P>0.05$. 


\section{RESULTS}

\section{Histological Results}

\section{Group I (Control)}

Light microscopic examination of Hx. and E. stained sections of the control subgroups IA, IB and IC showed almost the same regular structure of the adrenal cortex which was formed of three zones; the zona glomerulosa (ZG) that formed the thin subcapsular zone then the widest middle zone, zona fasciculata $(\mathrm{ZF})$ and the inner zone, zona reticularis (ZR) (Figure 1). Zona glomerulosa cells were arranged in irregular clusters and separated by trabeculae with hardly detected minute capillaries (Figure 2). ZF cells appeared polyhedral with foamy eosinophilic cytoplasm and they were separated by slit like capillaries

(Figure 3). ZR showed compact cells with more eosinophilic cytoplasm than fasciculata and they were arranged in cords close to the adrenal medulla (Figure 4). The gland was surrounded by thick capsule with spindle like cells and connective tissue fibers (Figure 2).

Semithin sections stained by toluidine blue showed ZG cells with ill distinct cell boundaries. Zona glomerulosa and ZF cells appeared with rounded vesicular nuclei and small cytoplasmic droplets that were more abundant in ZF with well distinct cell boundaries (Figures 5,6). The ZR cells appeared with a few cytoplasmic droplets and well distinct cell boundaries (Figure 7)

Masson's Trichrome stain showed regular parallel arrangement of thick collagen fibers in the capsule and in the extending trabeculae between ZG cells (Figure 8).

Examination of immunohistochemically stained sections for caspase 3 showed negative cytoplasmic reaction of adrenal cortical cells (Figures 9,10).

\section{Group II (MSG Group)}

Light microscopic examination of Hx. and E. stained sections of the group II showed disorganized structure of $\mathrm{ZG}$ and ZF (Figure 11). The ZG cells showed multiple intercellular spaces while, most of ZF cells appeared separated, darker with loss of foamy appearance (Figure 12), dilated congested capillaries with interstitial hemorrhage in the three zones were noted (Figures 13,14). Apparent thin capsule was also noted (Figure 12).

Semithin sections stained by toluidine blue showed ZG cells with an apparent increase in the cytoplasmic droplets (Figure 15). ZF cells were heavily loaded with cytoplasmic droplets with ill distinct cell boundaries (Figure 16). Some of ZF cells showed irregular dark nuclei (pyknotic) (Figure 17). Regular structure of ZR cells was noted (Figure 18).

Masson's Trichrome stain showed apparent decrease in collagen fibers of the capsule with irregular fibers in the extending trabeculae between ZG cells (Figure 19).

Examination of immunohistochemically stained sections for caspase 3 showed extensive cytoplasmic reaction of most of adrenal cortical cells of both $\mathrm{ZG}$ and ZF (Figures 20,21).

\section{Group III (MSG + Vitamin C)}

Light microscopic examination of Hx. and E. stained sections of the group III showed nearly regular adrenal structure with mild dilated congested capillaries, minimal intercellular spaces in $\mathrm{ZG}$ and $\mathrm{ZF}$ cells and the later appeared polyhedral and foamy (Figures 22,23). Apparent thick capsule was noted (Figure 22).

Semithin sections stained by toluidine blue showed apparent mild increase in the cytoplasmic droplets of some ZG and ZF cells with regular structure of ZR (Figures 24-26).

Masson's Trichrome stain showed nearly regular thick collagen fibers of the capsule and of the extending trabeculae between ZG cells (Fiure 27).

Examination of immunohistochemically stained sections for caspase 3 showed negative to mild cytoplasmic reaction of ZG and ZF cells (Figures 28,29).

\section{Morphometrical results}

A morphometric study was used for measuring the thickness of the adrenal capsule in microns and the number of caspase positive cells of $\mathrm{ZF} /$ field of all groups, values were mentioned in tables and column charts.

Statistical analysis revealed highly statistically significant difference for both the thickness of adrenal capsule and the number of caspase positive cells of $\mathrm{ZF} /$ field of the MSG group (group II) as compared to the control group (group I) with a $P$-value $<0.001$. Similarly, a highly significant difference for both measures between group II and MSG + Vitamin C (group III) has been found with a $P$-value $<0.001$. On the other hand, the difference between group I and group III for both measures were statistically non-significant with a $P$-value $>0.05$ (Tables 1 and 2). The comparisons between the morphometric results of the three groups were further illustrated in column (Charts 1 and 2).

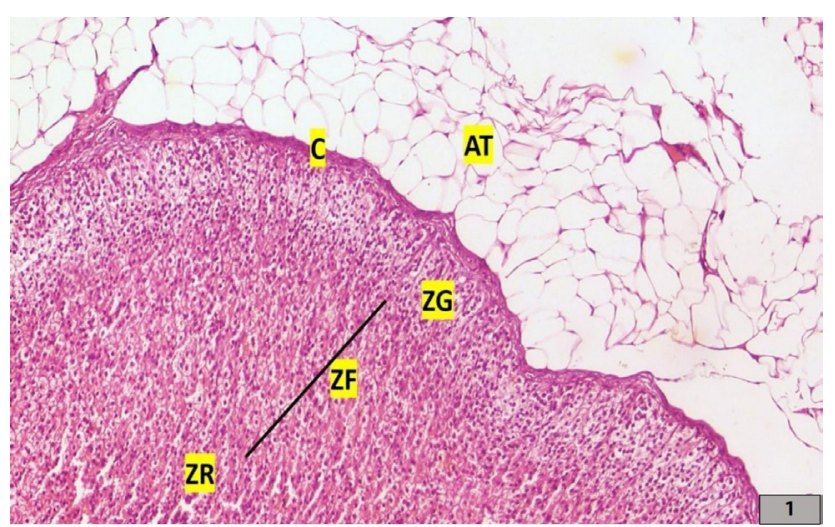

Fig. 1: A photomicrograph of a section of adrenal cortex of group I, showing the three layers of the adrenal cortex zona glomerulosa $(\mathrm{ZG})$, zona fasciculata $(\mathrm{ZF})$ and zona reticularis $(\mathrm{ZR})$. Notice the capsule (C) and the surrounding adipose tissue (AT). (Hx. \& E. X100) 


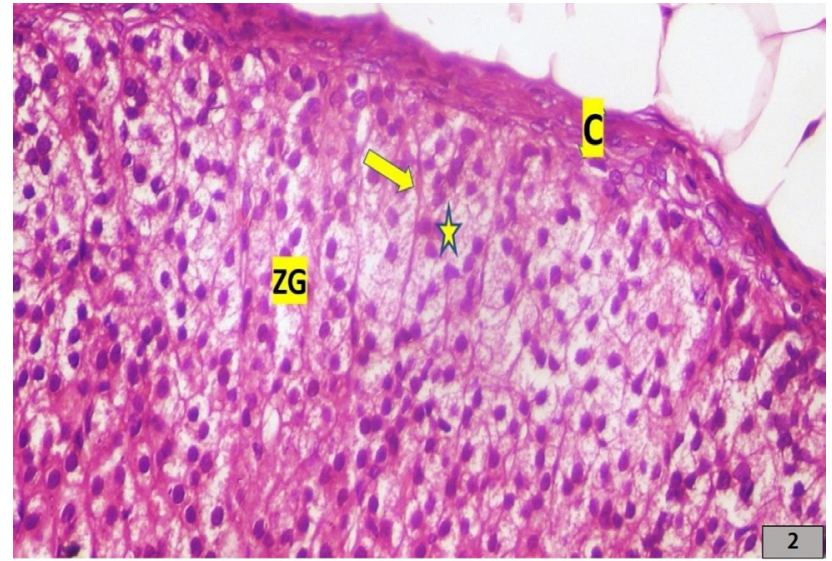

Fig. 2: A higher magnification of the previous photomicrograph of a section of adrenal cortex of group I, showing the capsule (C), zona glomerulosa cells ( $\mathrm{ZG}$ ) arranged in irregular clusters (star) and separated by trabeculae with hardly detected minute capillaries (arrow). (Hx. \& E. X400)

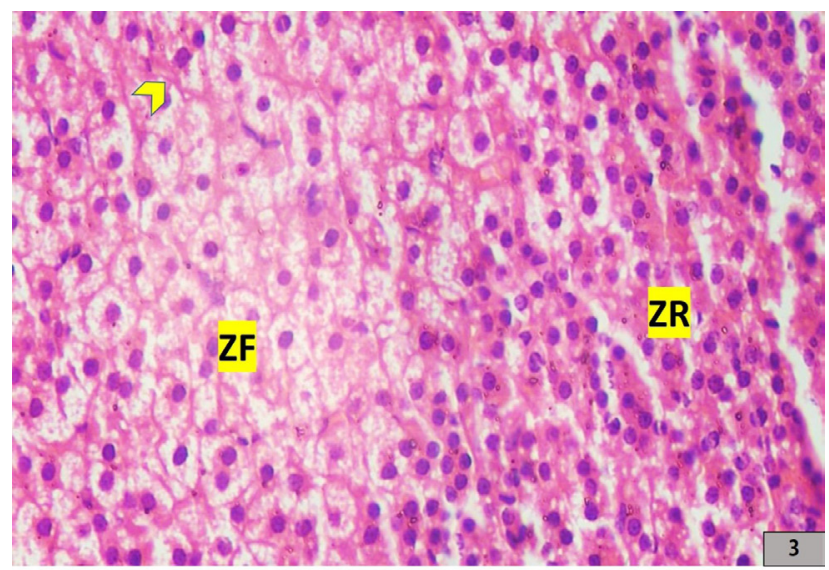

Fig. 3: A photomicrograph of a section of adrenal cortex of group I, showing zona fasciculata (ZF) polyhedral cells with foamy eosinophilic cytoplasm separated by slit like capillaries (arrowhead) and zona reticularis (ZR). (Hx. \& E. X400)

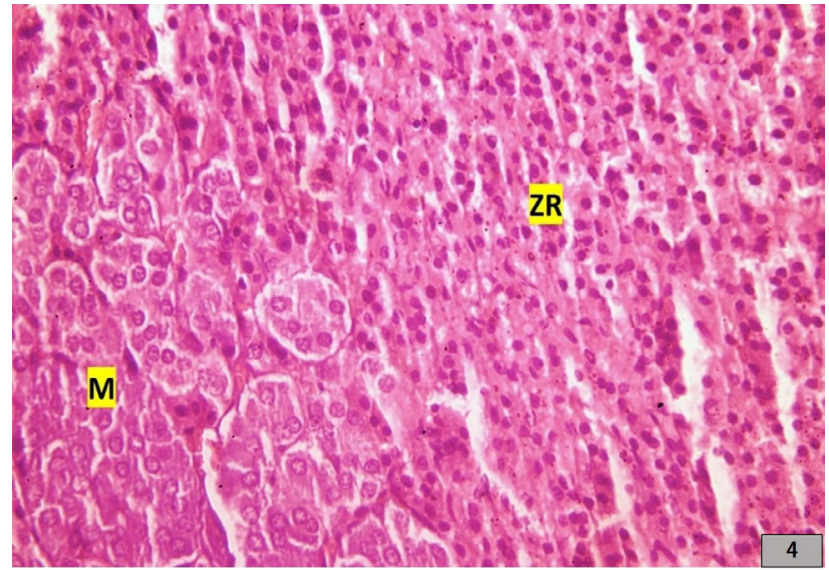

Fig. 4: A photomicrograph of a section of adrenal cortex and medulla of group I, showing zona reticularis (ZR), compact eosinophilic cells arranged in cords close to the adrenal medulla (M). (Hx. \& E. X400)

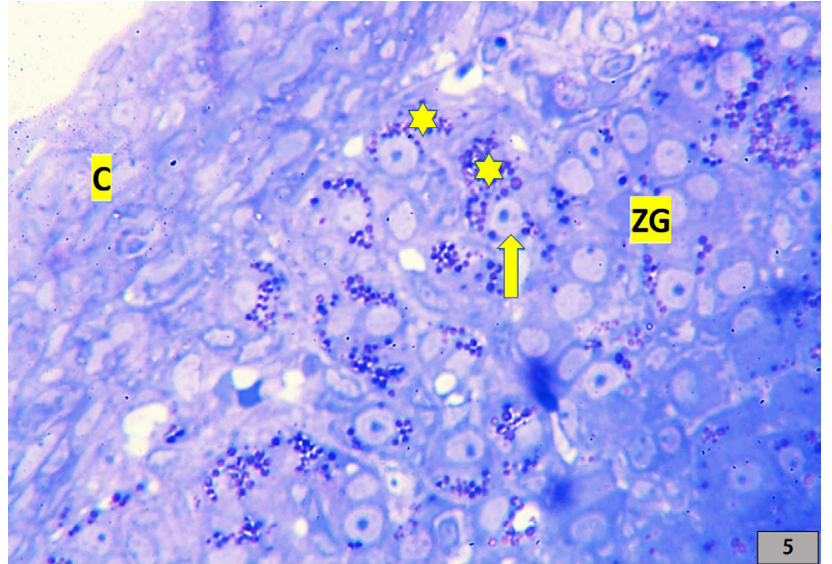

Fig. 5: A photomicrograph of a semithin section of adrenal cortex of group I, showing thick adrenal capsule $(\mathrm{C})$, zona glomerulosa cells (ZG) with ill distinct cell boundaries, the cells contained rounded vesicular nuclei with prominent nucleoli (arrow). Notice the small cytoplasmic droplets (stars). (Toluidine blue X1000)

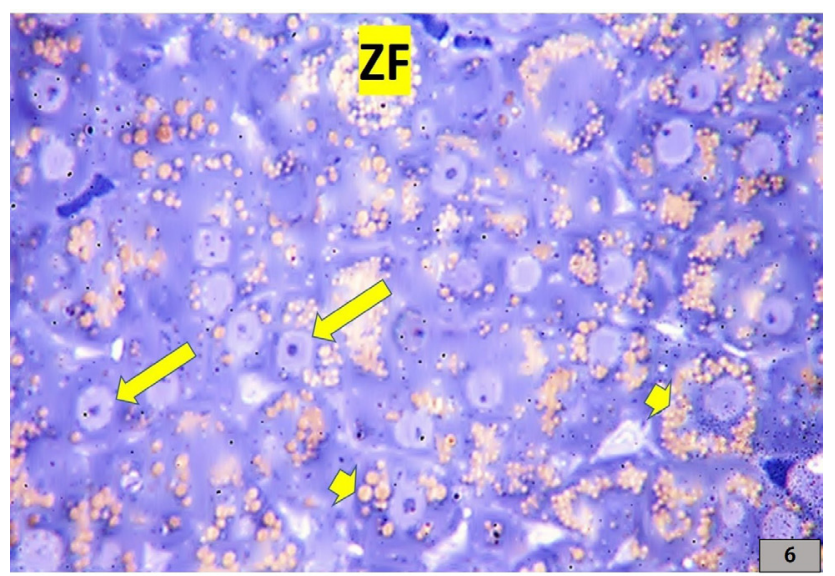

Fig. 6: A photomicrograph of a semithin section of adrenal cortex of group I, showing zona fasciculata cells (ZF) with rounded nuclei and prominent nucleoli (long arrows), the cytoplasm contained many small cytoplasmic droplets with well distinct cell boundaries (short arrows). (Toluidine blue X1000)

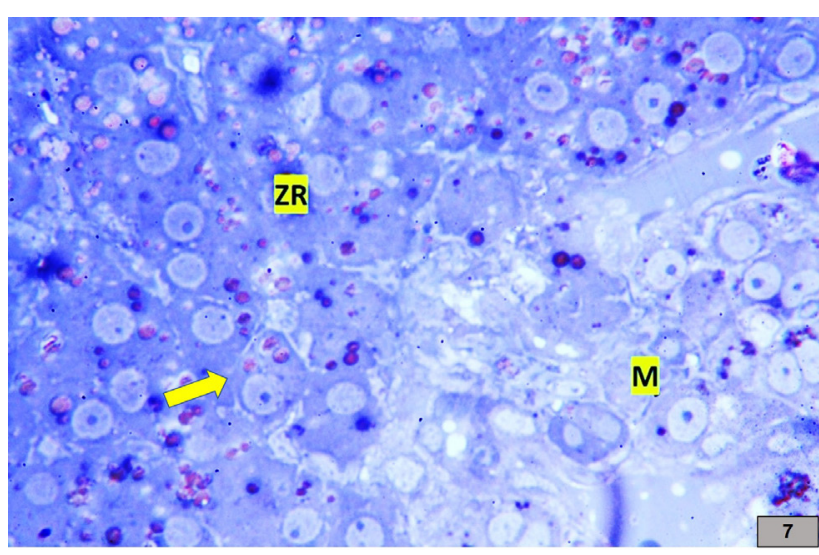

Fig. 7: A photomicrograph of a semithin section of adrenal cortex and medulla of group I, showing zona reticularis cells (ZR) with well distinct cell boundaries and a few cytoplasmic droplets (arrow), and the adrenal medulla (M). (Toluidine blue X1000) 


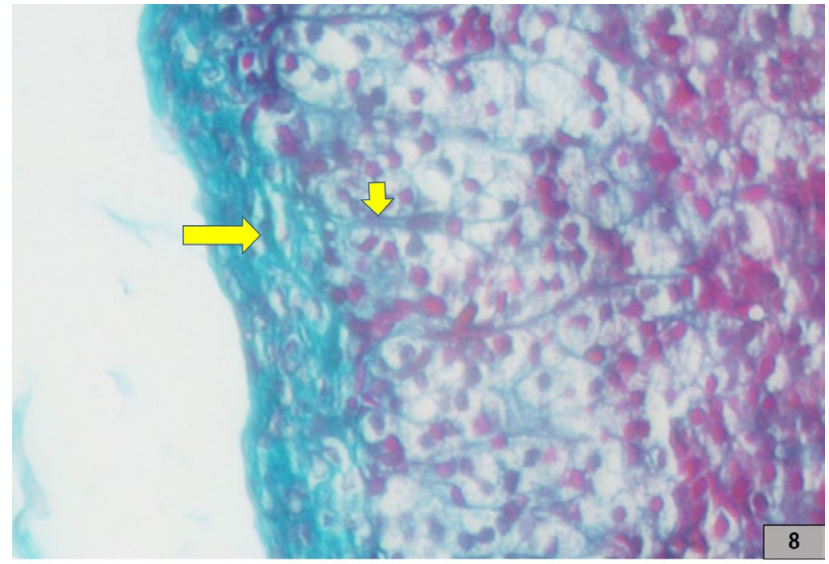

Fig. 8: A photomicrograph of a section of adrenal cortex of group I, showing thick regular collagen fibers of the capsule (long arrow) and in the extending trabeculae between ZG cells (short arrow). (Masson's trichrome X400)

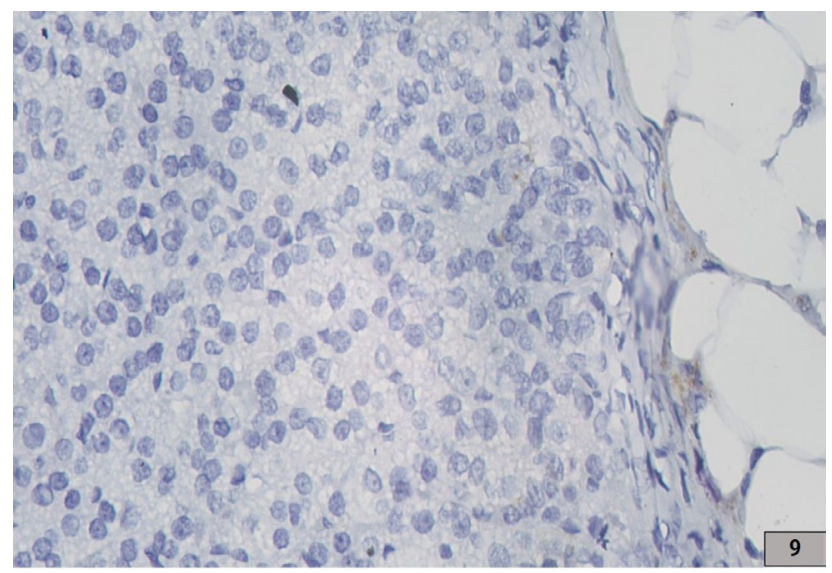

Fig. 9: A photomicrograph of a section of adrenal cortex of group I, showing negative cytoplasmic reaction for caspase-3 of adrenal cortical cells. (Caspase 3, X400)

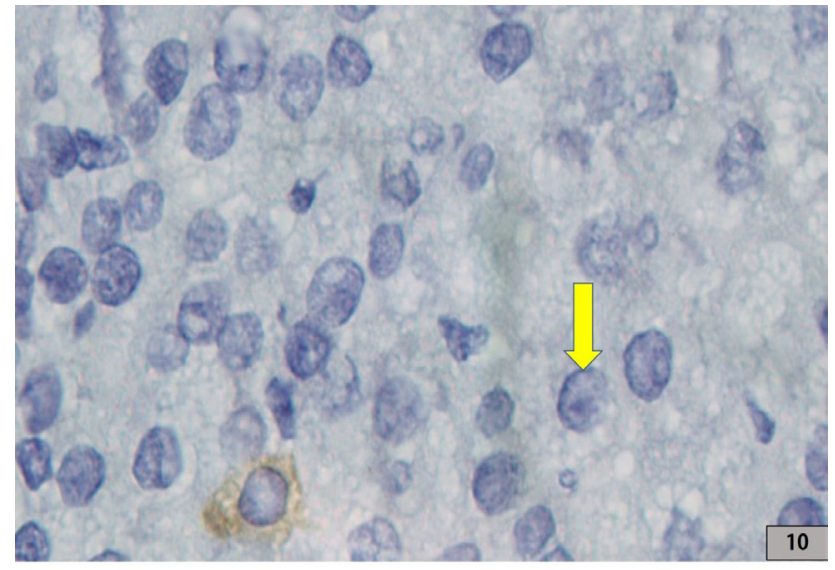

Fig. 10: A photomicrograph of a section of adrenal cortex of group I, showing negative cytoplasmic reaction for caspase-3 of ZF cells (arrow). (Caspase 3, X1000)

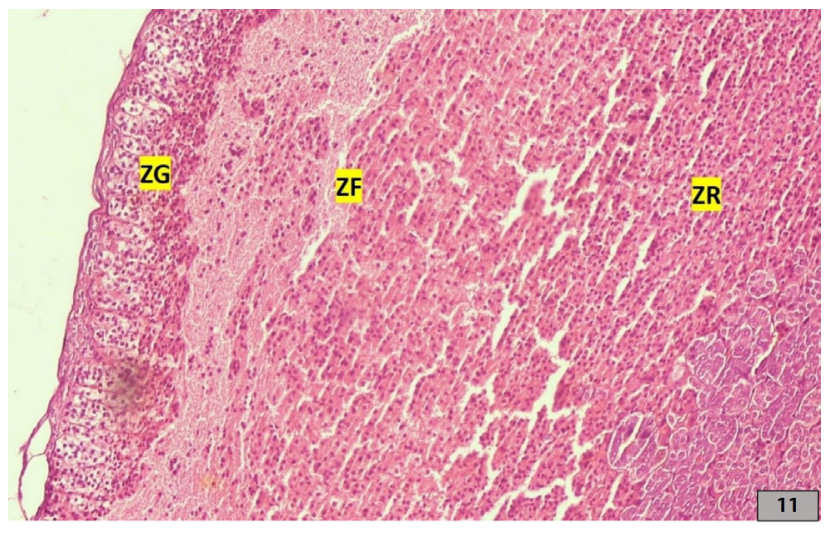

Fig. 11: A photomicrograph of a section of adrenal cortex of group II, showing disorganized adrenal structure of zona glomerulosa $(\mathrm{ZG})$ and zona fasciculata (ZF). Notice regular structure of zona reticularis (ZR). (Hx. \& E. X100)

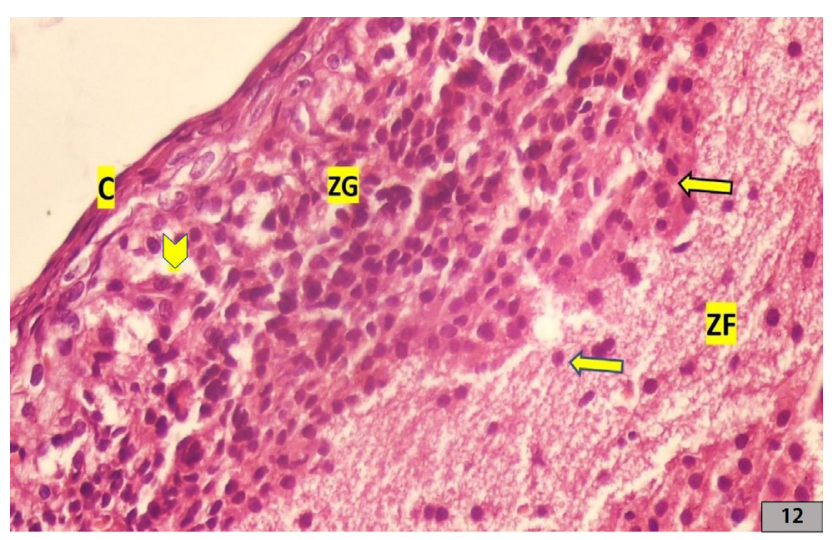

Fig. 12: A photomicrograph of a section of adrenal cortex of group II, showing disorganized zona glomerulosa cells (ZG) with multiple intercellular spaces (arrowhead), zona fasciculata cells (ZF) appeared disorganized separated, darker with loss of foamy appearance (arrows). Notice the apparent thin capsule (C). (Hx. \& E. X400)

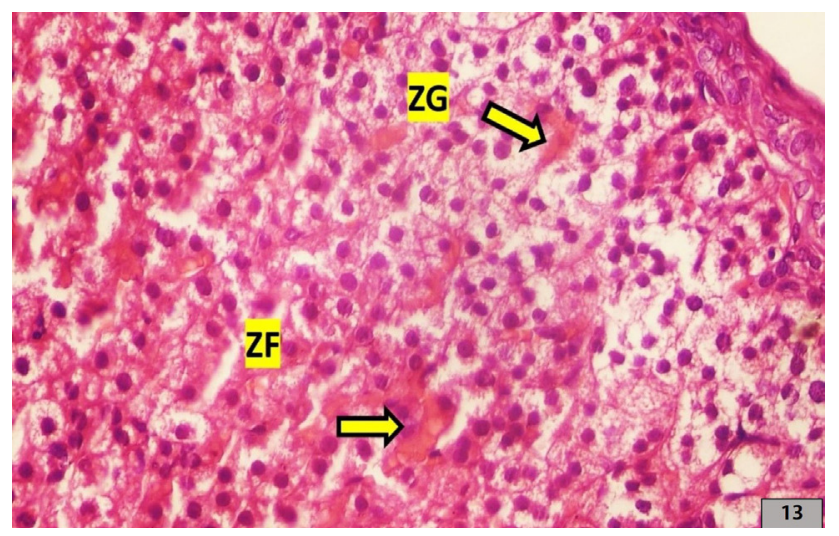

Fig. 13: A photomicrograph of a section of adrenal cortex of group II, showing dilated congested capillaries (arrows) in zona glomerulosa (ZG) and zona fasciculata (ZF). (Hx. \& E. X400) 


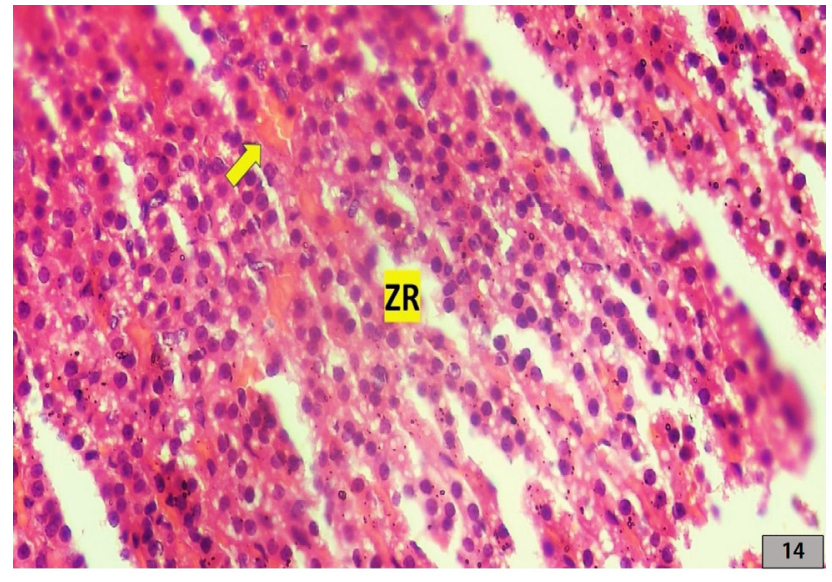

Fig. 14: A photomicrograph of a section of adrenal cortex of group II, showing dilated congested capillaries with interstitial hemorrhage (arrow) in zona reticularis (ZR). (Hx. \& E. X400)

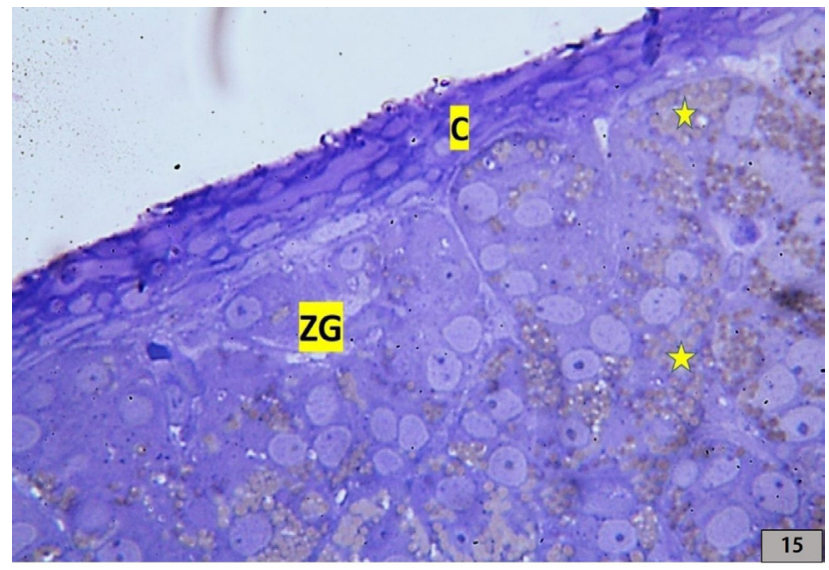

Fig. 15: A photomicrograph of a semithin section of adrenal cortex of group II, showing apparent thin adrenal capsule (C), zona glomerulosa cells $(\mathrm{ZG})$ with apparent increase in the cytoplasmic droplets (stars). (Toluidine blue X1000)

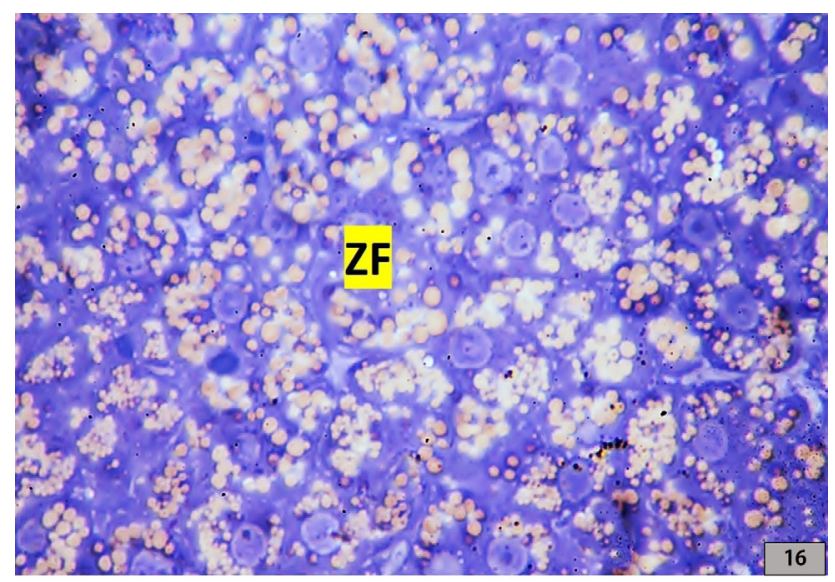

Fig. 16: A photomicrograph of a semithin section of adrenal cortex of group II, showing zona fasciculata cells heavily loaded by cytoplasmic droplets with ill distinct cell boundaries. (Toluidine blue X1000)

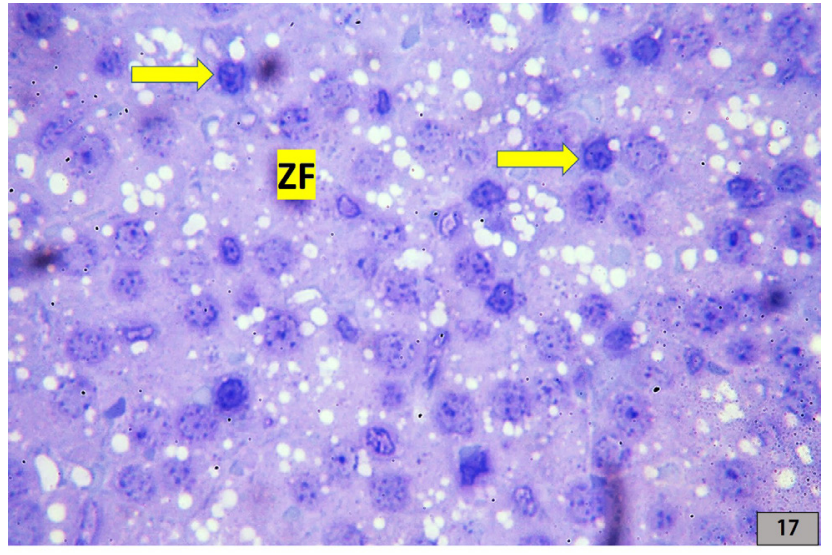

Fig. 17: A photomicrograph of a semithin section of adrenal cortex of group II. showing some zona fasciculata cells (ZF) with irregular dark nucleus (pyknotic) (arrows). Notice the loss of cell boundaries. (Toluidine blue X1000)

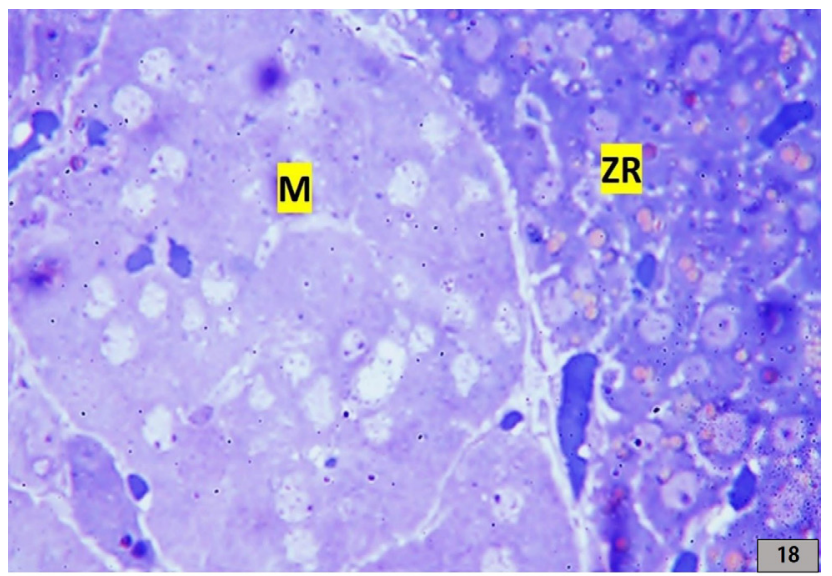

Fig. 18: A photomicrograph of a semithin section of adrenal cortex of group II, showing regular structure of zona reticularis (ZR), and the adrenal medulla (M). (Toluidine blue X1000)

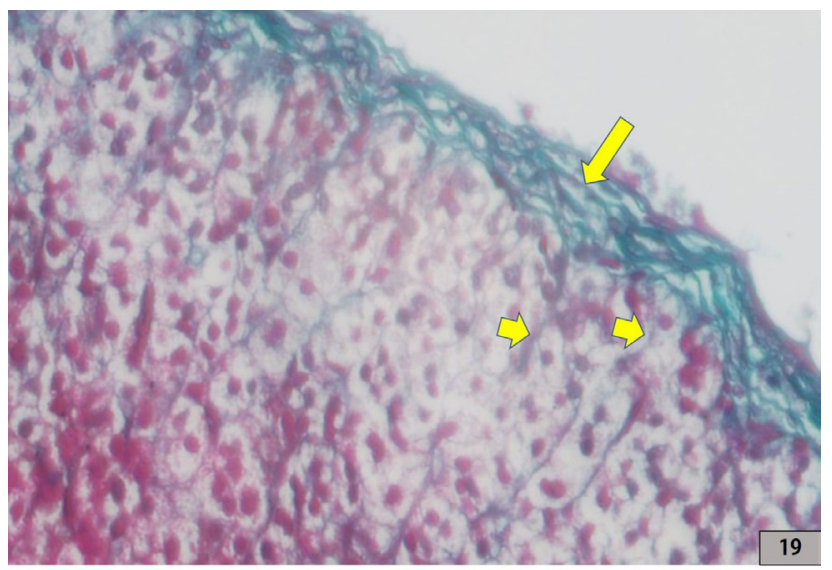

Fig. 19: A photomicrograph of a section of section of adrenal cortex of group II, showing apparent decrease in collagen fibers of the capsule (long arrow) with irregular fibers in the extending trabeculae between ZG cells (short arrows). (Masson's trichrome X400) 


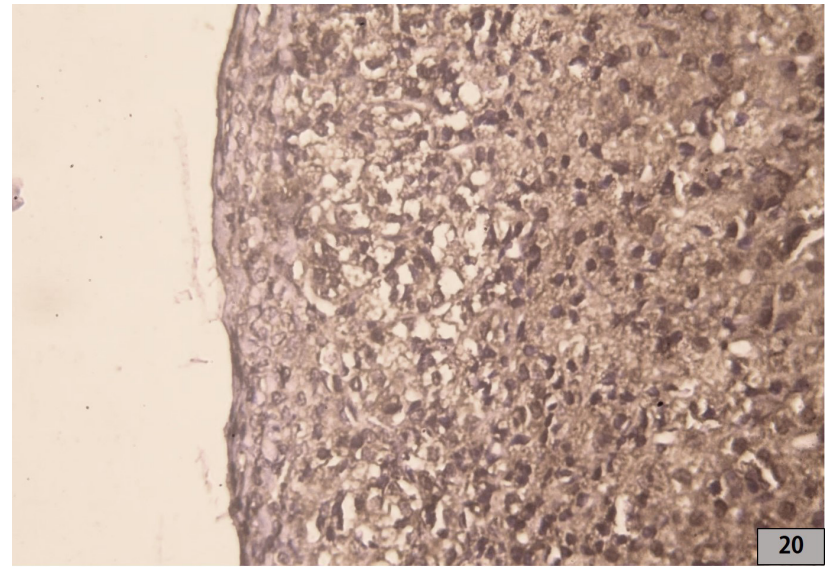

Fig. 20: A photomicrograph of a section of group II, showing extensive cytoplasmic reaction for caspase- 3 of adrenal cortical cells of both ZG and ZF (dark brown color). (Caspase 3, X400)

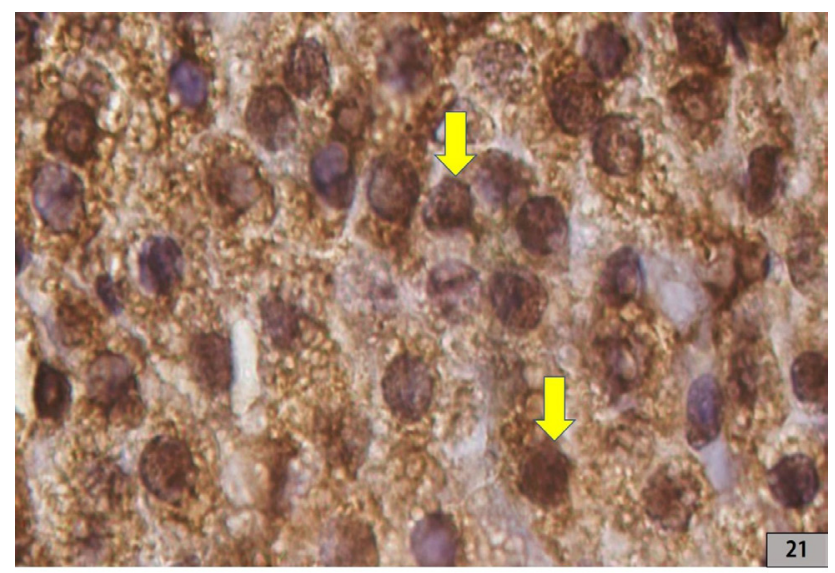

Fig. 21: A photomicrograph of a section of group II, showing extensive cytoplasmic reaction for caspase-3 (dark brown color) of ZF cells (arrows). (Caspase 3, X1000)

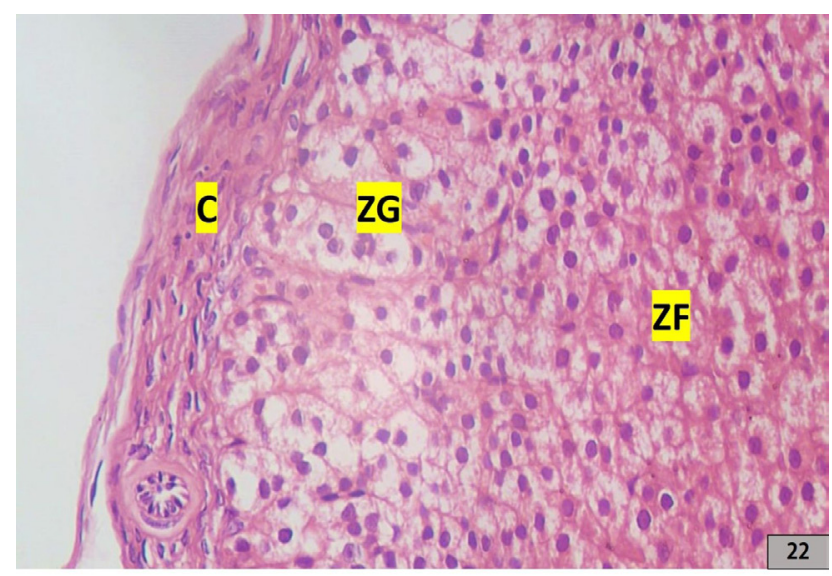

Fig. 22: A photomicrograph of a section of adrenal cortex of group III, showing thick capsule (C) and regular structure of ZG and ZF. (Hx. \& E. X400)

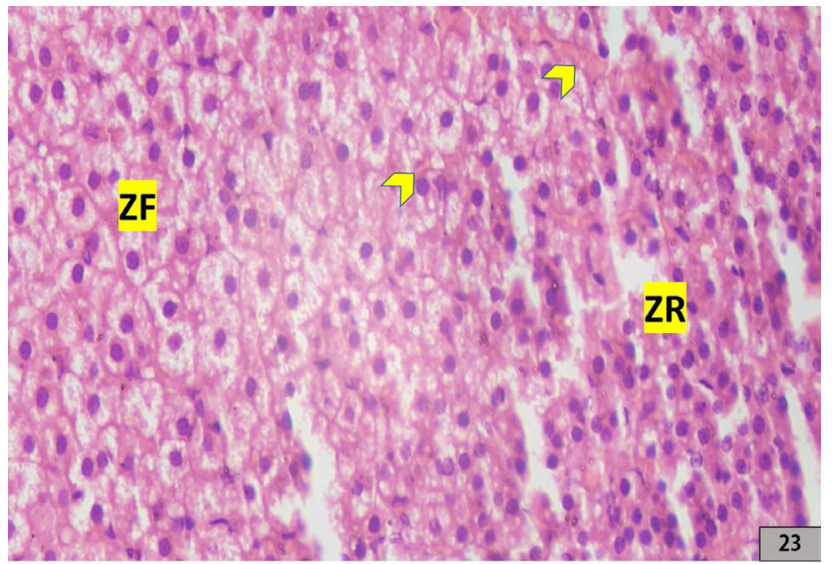

Fig. 23: A photomicrograph of a section of adrenal cortex of group III, showing foamy zona fasciculata cells (ZF) and zona reticularis cells (ZR) with mild dilated congested capillaries (arrowheads). (Hx. \& E. X400)

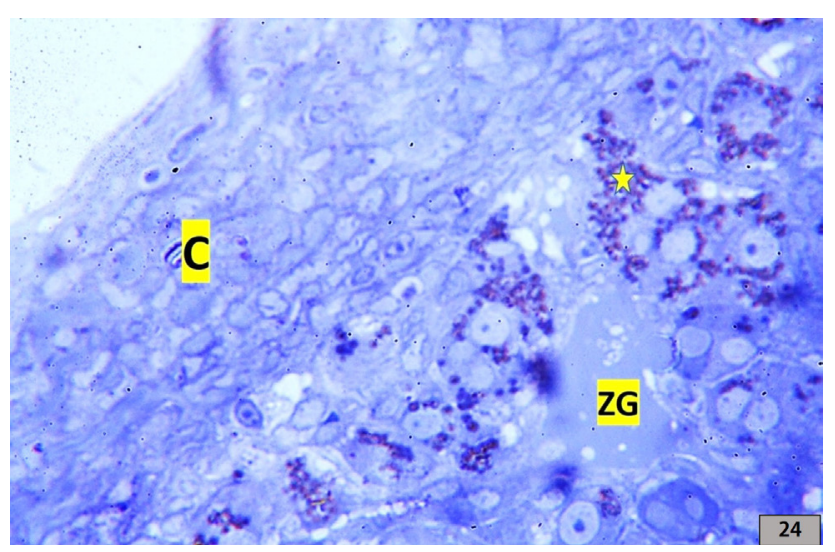

Fig. 24: A photomicrograph of a semithin section of adrenal cortex of group III, showing apparent thick capsule (C), zona glomerulosa cells $(\mathrm{ZG})$ with apparent mild increase in the cytoplasmic droplets (star). (Toluidine blue X1000)

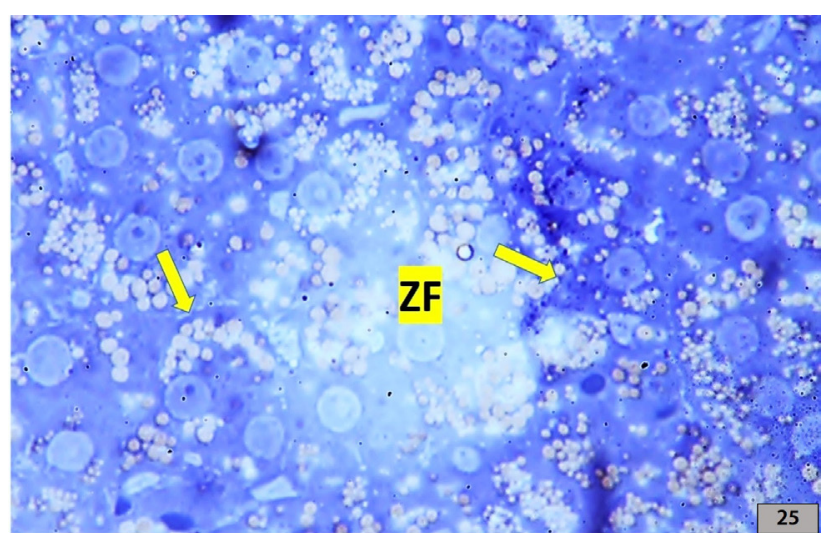

Fig. 25: A photomicrograph of a semithin section of adrenal cortex of group III, showing apparent mild increase in the cytoplasmic droplets (arrows) of zona fasciculata cells (ZF). (Toluidine blue X1000) 


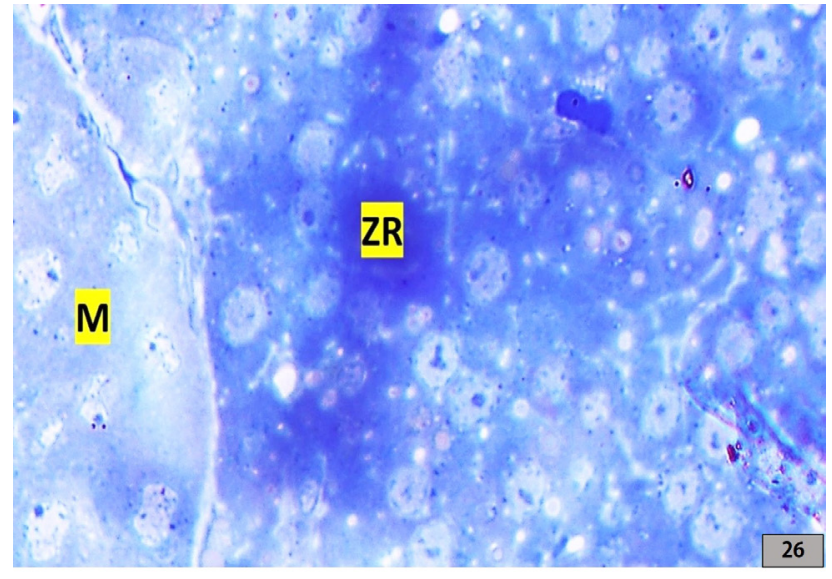

Fig. 26: A photomicrograph of a semithin section of adrenal cortex of group III, showing regular structure of zona reticularis (ZR) and adrenal medulla (M). (Toluidine blue X1000)

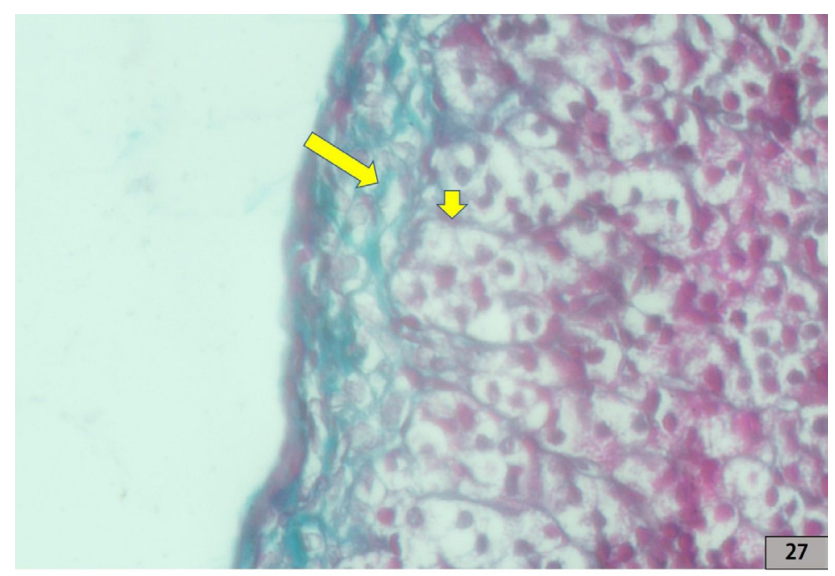

Fig. 27: A photomicrograph of a section of section of adrenal cortex of group III, showing nearly regular thick collagen fibers of the capsule (long arrow) and of the extending trabeculae between ZG cells (short arrow). (Masson's trichrome X400)

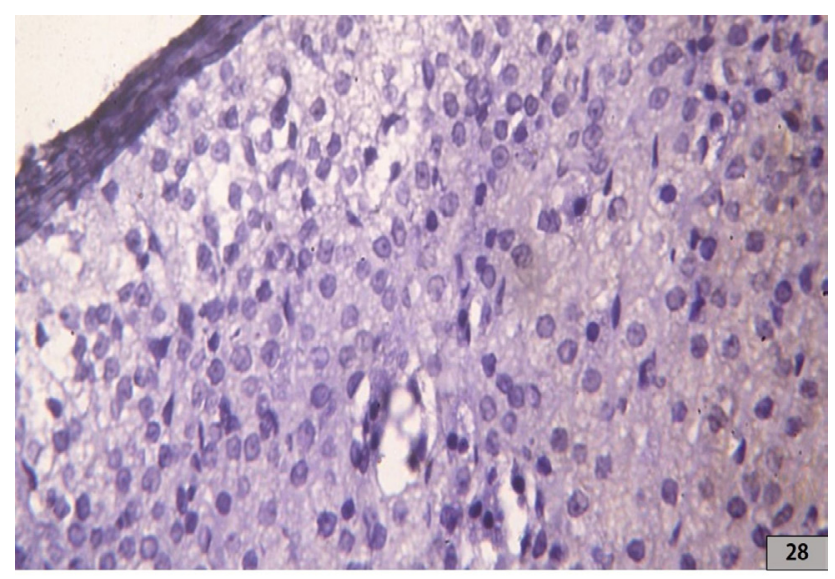

Fig. 28: A photomicrograph of a section of group III, showing negative to mild cytoplasmic reaction for caspase- 3 of $\mathrm{ZG}$ and ZF cells. (Caspase 3, X400)

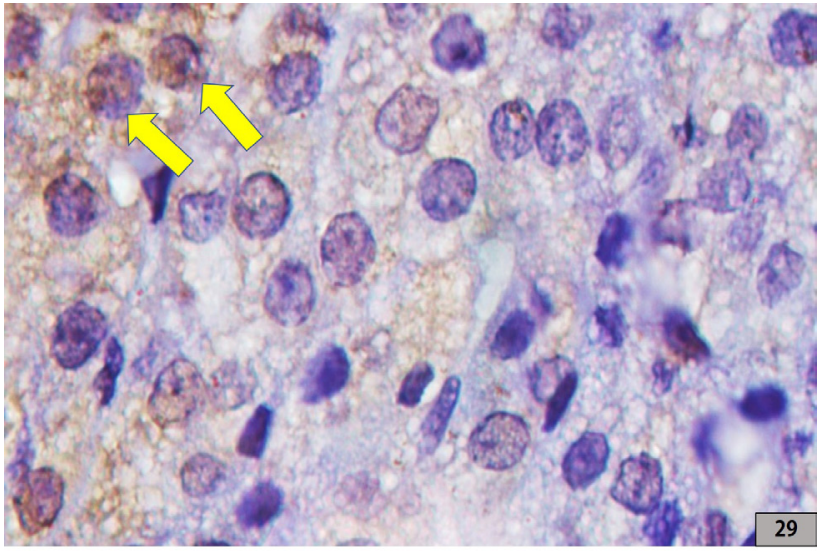

Fig. 29: A photomicrograph of a section of group III, showing mild cytoplasmic reaction for caspase-3 of some ZF cells (arrows). (Caspase 3, X1000)

Table 1: Comparing the thickness of the adrenal capsule of the three groups showing p-value either; non-significant $(*)$ or highly significant $(* *)$.

\begin{tabular}{|c|c|c|c|c|}
\hline & & $\begin{array}{c}\text { Group I } \\
\text { (Control) }\end{array}$ & $\begin{array}{l}\text { Group II } \\
\text { (MSG) }\end{array}$ & $\begin{array}{c}\text { Group III } \\
\text { (MSG + } \\
\text { Vitamin C) }\end{array}$ \\
\hline \multicolumn{2}{|c|}{$\begin{array}{l}\text { Thickness of adrenal } \\
\text { capsule (mean } \pm \\
\text { standard deviation) }\end{array}$} & $12.6 \pm 0.1$ & $7.6 \pm 0.6$ & $11.9 \pm 0.5$ \\
\hline \multirow{3}{*}{$\frac{\tilde{s}}{\omega}$} & $\begin{array}{l}\text { Between } \\
\text { Group I\&II }\end{array}$ & \multicolumn{3}{|c|}{$\mathrm{P}=0.0001^{* *}$} \\
\hline & $\begin{array}{c}\text { Between } \\
\text { Group II\&III }\end{array}$ & \multicolumn{3}{|c|}{$\mathrm{P}=0.0001^{* *}$} \\
\hline & $\begin{array}{l}\text { Between } \\
\text { Group I\&III }\end{array}$ & \multicolumn{3}{|c|}{$\mathrm{P}=0.6^{*}$} \\
\hline
\end{tabular}

Table 2: Comparing the number of caspase positive cells of ZF/ field of the three groups showing p-value either; non-significant $(*)$ or highly significant $(* *)$

\begin{tabular}{|c|c|c|c|c|}
\hline & & $\begin{array}{c}\text { Group I } \\
\text { (Control) }\end{array}$ & $\begin{array}{l}\text { Group II } \\
\text { (MSG) }\end{array}$ & $\begin{array}{c}\text { Group III } \\
(\text { MSG }+ \\
\text { Vitamin C) }\end{array}$ \\
\hline \multicolumn{2}{|c|}{$\begin{array}{l}\text { Number of caspase } \\
\text { positive cells of } \mathrm{ZF} / \text { field } \\
\text { (mean } \pm \text { standard } \\
\text { deviation) }\end{array}$} & $0.5 \pm 0.2$ & $11.3 \pm 1.0$ & $1.1 \pm 1.8$ \\
\hline \multirow{3}{*}{ 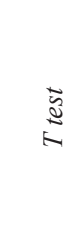 } & $\begin{array}{l}\text { Between } \\
\text { Group I\&II }\end{array}$ & \multicolumn{3}{|c|}{$\mathrm{P}=0.0001^{* *}$} \\
\hline & $\begin{array}{c}\text { Between } \\
\text { Group II\&III }\end{array}$ & \multicolumn{3}{|c|}{$\mathrm{P}=0.0001^{* *}$} \\
\hline & $\begin{array}{c}\text { Between } \\
\text { Group I\&III }\end{array}$ & \multicolumn{3}{|c|}{$\mathrm{P}=0.2^{*}$} \\
\hline
\end{tabular}




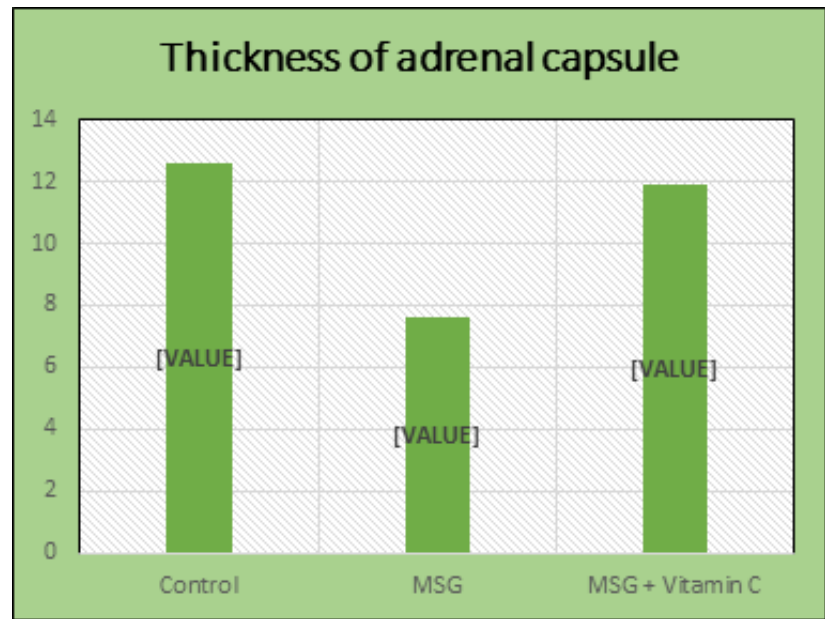

Column chart 1: Demonstrating the morphometric comparison between the three groups as regards; the thickness of the adrenal capsule in microns.

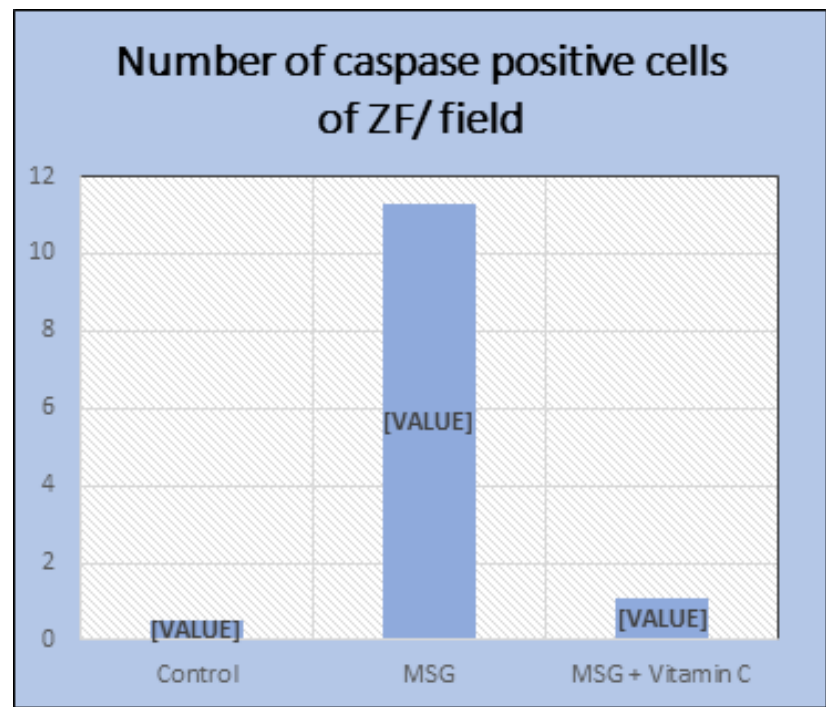

Column chart 2: Demonstrating the morphometric comparison between the three groups as regards; the number of caspase positive cells of $\mathrm{ZF} /$ field.

\section{DISCUSSION}

MSG toxicity to humans and experimental animals have been reported by many studies despite its unique taste stimulation and enhancement of appetite. Individual difference in tolerance to MSG toxicity was proved, but generally all suffer the same chemical reactions each time they ingest MSG that eventually exceed their tolerances ${ }^{[22]}$. The adrenal gland is one of the most common endocrinal organs susceptible to chemical induced injuries ${ }^{[16]}$.

The results of the present work revealed that MSG induced histopathological changes in rat adrenal cortex were mainly in ZF. Sections stained with Hx. and E. showed disorganized structure of $\mathrm{ZG}$ and $\mathrm{ZF}$. ZG cells showed multiple intercellular spaces while, most of ZF cells appeared separated, darker with loss of foamy appearance, dilated congested capillaries with interstitial hemorrhage in three zones were noted. Zona glomerulosa produces aldosterone, zone fasciculata produces glucocorticoids and zona reticularis produces sex steroids ${ }^{[23,24]}$. Carsia et al. ${ }^{[25]}$ reported that steroidogenic activities of adrenal gland were directly influenced by its zonal architecture. Aldosterone released by $\mathrm{ZG}$ is responsible to increase sodium reabsorption and to stimulate potassium excretion by the kidneys. Disturbances in this zone lead to electrolyte imbalance ${ }^{[24]}$. Seo et al. ${ }^{[15]}$ reported that, corticosterone release from $\mathrm{ZF}$, decreased in chronic MSG administration and explained that the decrease is due to overstimulated hypothalamus by excess accumulated glutamate with corticotropic releasing factor (CRF) hypersecretion and subsequent down regulation of the pituitary CRF receptor and decreased ACTH release.

Thinning of the adrenal capsule was noted in MSG group and this was further confirmed by the morphometric results that revealed highly statistically significant decrease in thickness of adrenal capsule of MSG group when compared to that of control group. Previous studies have revealed that adrenal maintenance involves cell conversion of ZG cells into ZF cells ${ }^{[26]}$ and the adrenal capsule is considered the signaling center that control cortical cells renewal as it is required to maintain adrenal zonation throughout life and to ensure continuous replacement of damaged cells ${ }^{[14]}$. Moreover, Masson's Trichrome stain revealed apparent decrease in collagen fibers of the capsule with irregular fibers in the extending trabeculae between ZG cells. Previous studies suggested that the extracellular matrix including collagen involved in the control of adrenal gland activities ${ }^{[27]}$ and that was clarified when fetal adrenal cortical cells were cultured on collagen-coated dishes and showed increased proliferation and activities ${ }^{[28]}$.

In addition, semithin sections stained by toluidine blue of the same group clarified the increase in the cytoplasmic droplets which was moderate in ZG and marked in ZF. Zona fasciculata cells also showed ill-defined cell boundaries and pyknotic nuclei. Adrenal cortical cells are considered a major site of cytoplasmic lipid storages used for steroidogenesis ${ }^{[16]}$. Disrupted steroidogenesis may occur as a result of oxidative damage. Therefore, cholesterol biosynthesis will be impaired with increased cytoplasmic accumulation of lipid droplets ${ }^{[29]}$. Moreover, Kawai et al. ${ }^{[30]}$ reported that cytoplasmic lipid droplets increased in adrenal hypo-functional state. Previous studies explained the mechanism of MSG damage on different tissue by its direct toxic effect on cells which is caused mainly by the presence of glutamate receptors as in hypothalamus, endocrine system and other organs or due to the decrease in ascorbic acid level which leads to imbalance in homeostasis of glutathione precursor (cysteine). This leads to depletion of intracellular glutathione and then reduced ability to protect against oxidative damage with subsequent oxidative stress and accumulation of free radicals ${ }^{[31-34]}$. No obvious changes detected in ZR cells of MSG group except for dilated congested blood vessels in-between the cells. Previous studies have proved the effect of MSG on $\mathrm{ZF}^{[16,23]}$ with minimal available data for its effect on ZG and ZR. 
However, Rosol et al., ${ }^{[24]}$ stated that chemically induced damage of adrenal cortex is more frequently affecting ZF and ZR in fetal adrenal cortex and Cekic et al. ${ }^{[35]}$ reported hyperplasia of both ZF and ZR in newborn rats treated with MSG.

Moreover, immunohistochemically staining for caspase 3 of the same group showed extensive cytoplasmic reaction of most of the adrenal cortical cells of both $\mathrm{ZG}$ and ZF, this was further confirmed by the morphometric results that revealed highly statistically significant increase in the number of caspase positive cells of ZF when compared to that of the control group and which was an indicator of increased cellular apoptosis ${ }^{[36]}$. Caspase 3 is known to be activated by the two main apoptotic pathways, the receptor pathway (extrinsic) and the mitochondrial pathway (intrinsic). The intrinsic pathway is activated in response to oxidative stress ${ }^{[37]}$.

On the other hand, Hx. and E. stained sections of group III that received MSG with vitamin $\mathrm{C}$ showed relatively preserved adrenal cortical structure with mild dilated congested capillaries in the three zones. Apparent thick capsule was noted, and this was further confirmed by the morphometric results that revealed a non-significant difference between group III and the control group and a highly significant difference between group II and group III regarding the thickness of the capsule.

Moreover, Masson's Trichrome stained sections showed regular thick collagen fibers of the capsule and of the extending trabeculae between ZG cells close to that of the control group. The adrenal gland is one of the richest organs of vitamin $\mathrm{C}$ in the body. The glands can accumulate vitamin $\mathrm{C}$ under normal physiological conditions and act as a depot of vitamin $\mathrm{C}$ which acts as a cofactor for both adrenal catecholamine and steroidogenesis ${ }^{[38,39]}$. Studies have confirmed the crucial role of vitamin $\mathrm{C}$ on adrenal cortex as vitamin $\mathrm{C}$ deficiency proved to decrease plasma level of corticosterone and altered the morphology of mitochondrial membrane of adrenal cortical cells ${ }^{[40]}$

Semithin sections stained by toluidine blue of the same group showed zona glomerulosa and zona fasciculata cells with mild increase in the cytoplasmic lipid droplets. Vitamin $\mathrm{C}$ proved to protect $\mathrm{ZF}$ against free radicals released by nicotine ${ }^{[41]}$ and prevented the MSG induced damage in rat spleen ${ }^{[42]}$.

Minimal apoptotic cells were detected by immunohistochemically staining for caspase 3 of both ZG and ZF and this was further confirmed by the morphometric results that revealed a non-significant difference between group III and the control group and a highly significant difference between group II and group III regarding the number of caspase positive cells of ZF. Hartel et al.$^{[43]}$ stated that vitamin $\mathrm{C}$ is one of the most important physiological antioxidants. It exerts its action by entering the mitochondria, accumulates as ascorbic acid which in turn inhibit oxidative mitochondrial DNA damage. In addition, it decreases lipid peroxidation either directly or by regenerating the antioxidant vitamin $\mathrm{E}^{[44]}$.

\section{CONCLUSION}

MSG led to histoarchitectural changes of adrenal cortex. However, vitamin $\mathrm{C}$ greatly improved such changes. Thus, it could be considered as a promising protector for ameliorating MSG induced adrenal hazards.

\section{CONFLICTS OF INTEREST}

There are no conflicts of interest.

\section{REFERENCES}

1. Abdel-Reheim ES, Abdel-Hafeez HA, Mahmoud, $\mathrm{BM}$ and Abd-Allah EN: Effect of food additives (monosodium glutamate and sodium nitrite) on some biochemical parameters in albino rats. Int J. Bioassays. (2014) 3 (8): 3260-3273.

2. Bojanić V, Bojanić Z, Ajman S, Savić T, Jakovljević V, Najman S, et al. Diltiazem prevention of toxic effects of monosodium glutamate on ovaries in rats. Gen. Physiol. Biophys. Special issue. (2009) 28:149-154.

3. Hermanussen M, Garcia AP, Sunder M, Voigt M, Salazar V and Tresguerres JA: Obesity, voracity, and short stature, the impact of glutamate on the regulation of appetite. Eur J Clin Nutr. (2006) 60:25-31.

4. Williams AN and Woessner KM: Monosodium glutamate allergy: menace or myth? Clinical \& Experimental Allergy. (2009) 39: 640-646.

5. Igwebuike UM, Ochiogu IS, Ihedinihu BC, Ikokide JE, and Idika ID: The effects of oral administration of monosodium glutamate $(\mathrm{msg})$ on the testicular morphology and cauda epididymal sperm reserves of young and adult male rats. Vet. arhiv. (2011) 81 (4):525-534.

6. Hlinák Z, Gandalovicová D and Krejcí I: Behavioral deficits in adult rats treated neonatally with glutamate. Neurotoxicol. Teratol. (2005) 27(3):465-473.

7. Narayanan SN, Kumar RS, Paval J and Nayak $\mathrm{S}$ : Effects of ascorbic acid on the monosodium glutamate-induced neurobehavioral changes in peri-adolescent rats. Bratisl Lek Listy. (2010) 111 (5): 247-252.

8. Egbuonu AC, Ejikeme PM and Obasi LN: Monosodium glutamate: Potentials at inducing prostate pathologies in male Wistar rats. African Journal of Biotechnology. (2010) 9(36): 5950-5954.

9. Ismail NH: Assessment of DNA damage in testes from young wistar male rat treated with monosodium glutamate. Life Science Journal. (2012) 9 (1): 930:939

10. Eweka AO, Eweka A and Om'iniabohs F: Histological studies of the effects of monosodium glutamate of the fallopian tubes of adult female Wistar rats. North American Journal of Medical Sciences. (2010) 2(3): 146-149.

11. Ahmed FE: Effect of diltiazem on the changes induced by monosodium glutamate in the ovary of 
adult rats: histological and immunohistochemical study. The Egyptian Journal of Histology. (2011) 34 (3): 586-595.

12. Naidu KA: Vitamin $C$ in human health and disease is still a mystery? An overview Nutrition Journal (2003) 2(7):1-10.

13. Iqbal K, Khan A and Khattak MM: Biological significance of ascorbic Acid (vitamin $\mathrm{C}$ ) in human health - A Review. Pakistan Journal of Nutrition. (2004): 3 (1): 5-13.

14. Vidal V, Sacco S, Rocha AS, da Silva F, Panzolini C, Dumontet $\mathrm{T}$, et al. The adrenal capsule is a signaling center controlling cell renewal and zonation Rspo3. Genes \& Development. (2016) 30:1389-1394.

15. Seo HJ, Ham HD, Jin HY, Lee WH, Hwang HS, Park SA, et al. Chronic administration of monosodium glutamate under chronic variable stress impaired hypothalamic-pituitary-adrenal axis function in rats. Korean J Physiol Pharmacol. (2010) 14:213-221.

16. Abdo FK, Hassan ZA, Mohamed DA and Mousa HS Monosodium glutamate induced histological change in the zona fasciculata of rats' adrenal and the possible amelioration effect of vitamin $\mathrm{C}$ supplementation. Journal of Medicine and Health Sciences Research. (2018) 1(1): 1-7.

17. Tawfik MS and Al-Badr N: Adverse Effects of Monosodium Glutamate on liver and kidney functions in adult rats and potential protective effect of vitamins $\mathrm{C}$ and E. Food and Nutrition Sciences. (2012) 3: 651-659.

18. Drury RAB, and Wallington EA: Carleton's Histological Technique. 5th ed. Oxford, New York, Toronto: Oxford University Press (1980) p.237.

19. Chandler N: The Masson trichrome staining methods in routine laboratory use. stain technology journal. (2009) 8 (3): 101-110.

20. Stenberg L, Kanje M, Dolezal K and Dahlin LB: Expression of activating transcription factor 3 (ATF 3) and caspase 3 in Schwann cells and axonal outgrowth after sciatic nerve repair in diabetic BB rats. Neuroscience letters. (2012) 515 (1): 34-38.

21. Bancroft JD and Stevens A: Theory and practice of histological techniques. 4th ed. Churchill Livingstone: Edinburgh. (1996) P. 433-472.

22. Dixit SG, Rani P, Anand A, Khatri K, Chauhan $\mathrm{R}$ and Bharihoke $\mathrm{V}$ : study the effect of monosodium glutamate on histomorphometry of cortex of kidney in adult albino rats. Ren Fail. (2014) 36(2): 266-270.

23. El-Helbawy NF, Radwan DA, Salem MF and El-Sawaf ME: Effect of monosodium glutamate on body weight and the histological structure of the zona fasciculata of the adrenal cortex in young male albino rats. Tanta medical journal. (2017) 45(2):104-113.
24. Rosol TJ, Yarrington JT, Latendresse J and Capen CC: Adrenal gland: structure, function, and mechanisms of toxicity. Toxicologic Pathology. (2001) 29(1):41- 48.

25. Carsia RV, Tilly KI and Tilly JL: Hormonal modulation of apoptosis in the rat adrenal gland in vitro is dependent on structural integrity. Endocrine. (1997) 7: $377-381$

26. Freedman BD, Kempna $\mathrm{PB}$ and Carlone DL: Adrenocortical zonation results from lineage conversion of differentiated zona glomerulosa cells. Dev Cell. (2013) 26: 666-673.

27. Chamoux E, Otis M and Gallo-Payet N: A connection between extracellular matrix and hormonal signals during the development of the human fetal adrenal gland. Brazilian Journal of Medical and Biological Research. (2005) 38: 1495-1503.

28. Chamoux E, Narcy A, Lehoux JG and Gallo-Payet $\mathrm{N}$ : Fibronectin, laminin and collagen IV as modulators of cell behavior during adrenal gland development in the human fetus. Journal of Clinical Endocrinology and Metabolism. (2002) 87: 1819-1828.

29. Elshennawy WW and Aboelwafa RH: Structural and ultrastructural alterations in mammalian adrenal cortex under influence of steroidogenesis inhibitors drug. J Am Sci. (2011) 7(8):567-76.

30. Kawai K, Sugikhar A and Tsuchiyama H: The effect of low potassium diet on the glomerular zone of the adrenal cortex of rat. Pathol Intern. (1979) 29: 351-362.

31. Okwudiri OO, Sylvanus AC and Peace IA: Monosodium glutamate induces oxidative stress and affects glucose metabolism in kidney of rats. Int. J. of Biochem. Reas. \& Rev. (2012) 2(1):1-11.

32. Giovambattista A, Suescun M, Nessralla C, França LR, Spinedi E, and Calandra RS Modulatory effects of leptin on leydig cell function of normal and hyperleptinemic rats. Neuroendocrinology (2003) 78: 270-279.

33. Moreno G, Perello M, Gaillard RC and Spine E: Orexin a stimulates hypothalamic-pituitary-adrenal (HPA) axis function, but not food intake in the absence of full hypothalamic NPY-ergic activity. Endocrine. (2005) 26: 99-106.

34. Farmobi $\mathrm{E}$ and Onyema O: Monosodium glutamate- induced oxidative damage and genotoxicity in the rat modulatory role of vitamin $\mathrm{C}$, vitamin $\mathrm{E}$ and quercetin. Hum Exp Toxicol. (2006) 25: 251-259.

35. Cekic S, Filipovic M, Pavlovic V, Ciric M, Nesic M, Zorica Jovic, et al. Histopathologic changes at the hypothalamic, adrenal and thymic nucleus arcuatus in rats treated glutamate. Acta Medica Medianae. (2005) 44 (3): $35-42$. 
36. Luiz F, Camila R, Carla C, Ricardo S, Maria C, José $\mathrm{M}$, et al. Melatonin action in apoptosis and vascular endothelial growth factor in adrenal cortex of pinealectomized female rats. Rev Bras Ginecol Obstet. (2010) 32(8):374-380.

37. Green DR and Kroemer G: The pathophysiology of mitochondrial cell death. Science. (2004) 30:626-629.

38. Padayatty SJ, Doppman JL, Chang R, Wang Y, Gill $\mathrm{J}$, Papanicolaou DA, et al. Human adrenal glands secrete vitamin $\mathrm{C}$ in response to adrenocorticotrophic hormone, Am J Clin Nutr. (2007) 86:145-149.

39. Djurasevic S, Cvijic G, Djordjevic J Djordjevic I, Jasnic N, Vujovic P: The effect of ascorbate supplementation on the activity of antioxidative enzymes in the rat hypothalamus and adrenals. Gen Physiol Biophys. (2009) 28: 47-52.

40. Patak P1, Willenberg HS and Bornstein SR: Vitamin $\mathrm{C}$ is an important cofactor for both adrenal cortex and adrenal medulla. Endocr Res. (2004) 30(4):871-5.

41. Abdel-Hamid G: Ameliorative effect of vitamin C on nicotine-induced histological and ultrastructural changes in zona fasciculata in albino rats. MOJ Anat and Physiol. (2018) 5(2):120-125.

42. Mohamed DS, Abdelhaliem NG and Zakaria AM: Histological and immunohistochemical study of the possible protective effect of ascorbic acid on the toxic effect of monosodium glutamate on the spleen of adult male albino Rat. The Egyptian journal of histology. (2017) 40(1):94-104.

43. Hartel C, Strunk T, Bucsky P and Schultz C: Effects of vitamin $\mathrm{C}$ on intracytoplasmic cytokine production in human whole blood monocytes and lymphocytes. Cytokine. (2004) 27: 101-106.

44. Adikwu E and Deo O: Hepatoprotective Effect of Vitamin C (Ascorbic Acid). Pharmacology \& Pharmacy. (2013) 4: 84-92. 


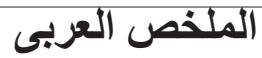

\title{
الاور الوقائي المحتمل لفيتامين ج ضد التغيرات الناجمة عن الغلوتامات أحادية الصوديوم على بنية القشرة الكظرية لأكر الجرذ الابيض البالغ: دراسة هستولوينة وهستو كيميائية مناعية الجزية
}

\author{
ايناس أنور بخيت وماريان مختار شكرى \\ قسم التشريح وعلم الأجنة كلية الطب جامعة عين شمس
}

مقدمة: تستخدم الغلوتامات أحادية الصوديوم كمحس للطعم وقد أثبت ان الغلوتامات أحادية الصوديوم تسبب الكثير من الأمر اض و الأضر ار المؤكسدة. يحتوي فيتامين ج على خاصية مضادة للأكسدة. الهدف: يهدف هذا العمل إلى دراسة الدور الوقائي المحتمل لفيتامين جئ ضدئ التغيرات الناجمة عن الغلوتامات أحادية الصوديوم على بنية القشرة الكظرية لذكر الجرذ لابيض البالغ. المواد والطرق المستخدمة: تم استخدام خمسة واربعين ذكرًا من الجرذان البيضاء في هذه الدراسة، الذين تتراوح

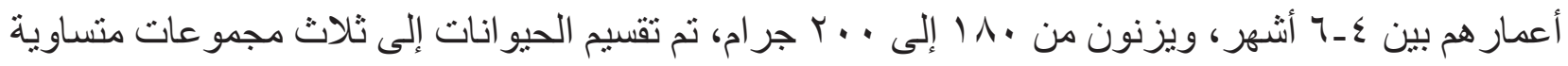
المجموعة الأولى: كانت تتألف من خمسة عشر جرذا وتم تقسيمها إلى ثلاث مجمو عات فرعية متساوية: المجموعة الفر عية IA: شملت 0 جرذان وتم الاحتفاظ بها كمجمو عه ضابطه سلبية المجموعة الفرعية IB: شملت ه جرذان و تلقت أ مل ماء مقطر يوميا لمدة م أسابيع. المجمو عة الفرعية IC: شملت 0 جرذان و تلقت فيتامين ج يوميا لمدة م أسابيع. المجمو عة الثانية: شملت خمسة عشر جرذا حيث تلقو ا الغلوتامات أحادية الصوديوم لمدة ^ أسابيع. المجمو عة الثالثة: شملت خمسة عشر جرذا حيث تلقو الغلوتامات أحادية الصوديوم مع فيتامين ج لمدة 1 أسابيع. النتائج: كثفت الدر اسة الحالية أن الغلوتامات أحادية الصوديوم تسبيت في تغييرات نسيجية في بنية القشرة الكظرية وزيادة تر اكم القطير ات السيتوبلازمية مع ترقق الغشاء المحيط. وقد كثفت المجمو عة الثالثة التي تلقت فيتامين ج تحسنا واضحا لهذه التغيير ات. الخلاصة: اوضحت هذه الدر اسة ان الغلوتامات أحادية الصوديوم ادت إلى تغيير ات فى قشرة الغدة الكظرية. وقد ادى استخدام فيتامين ج الى تحسن كبير لهذه التغيير ات. 